\title{
Anthraxolite-Uranium Mineral: Composition, Structural Features and Genesis
}

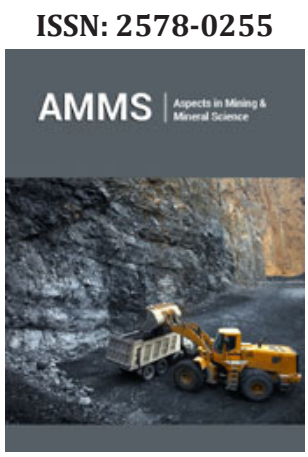

*Corresponding author: Pavel Straka, Institute of Rock Structure and Mechanics, Czech Academy of Sciences, Czech Republic

Submission: 眥 October 01, 2020

Published: 眥 November 13, 2020

Volume 5 - Issue 5

How to cite this article: Pavel Straka. Anthraxolite-Uranium Mineral: Composition, Structural Features and Genesis. Aspects Min Miner Sci. 5(5). AMMS. 000623. 2020. DOI: 10.31031/AMMS.2020.05.000623

Copyright@ Pavel Straka, This article is distributed under the terms of the Creative Commons Attribution 4.0 International License, which permits unrestricted use and redistribution provided that the original author and source are credited.

\section{Pavel Straka*}

Institute of Rock Structure and Mechanics, Czech Academy of Sciences, Czech Republic

\begin{abstract}
The most common uranium minerals are uraninite, coffinite and ningyoite. From a mineralogical point of view, anthraxolite is particularly interesting because it is a mixture of bitumen, uraninite and a small amount of coffinite while its composition has been significantly influenced by radiation metamorphism. As a mineral, it is light, hard, crumble, black in color with a brownish cut, matte sheen and a conchoidal fracture. Anthraxolite is always bound to the accumulation of uraninite, often metasomatically replacing uraninite. In the case of uranium deposit in Príbram, Czech Republic, the anthraxolite formation is the result of the transformation of organic matter into bitumens in the sediments of the Upper Proterozoic and Lower Cambrian, mobilization and transport of these bitumens by hydrothermal fluids into uranium deposit, and - after incorporation of uraninite particles / fragments - the radiation effect of uranium radionuclides causing the polycondensation of aromatic hydrocarbons in the bituminous mass and a change in its properties.
\end{abstract}

Keywords: Minerals; Uranium; Chemical composition; Coal

Basic Description

Table 1: Composition of anthraxolites from Central Europe with different uranium content (wt.\%).

\begin{tabular}{|c|c|c|c|c|c|c|c|c|}
\hline \multirow{2}{*}{ U } & \multicolumn{4}{|c|}{ Proximate Analysis (Dry Basis) } & \multicolumn{5}{|c|}{ Ultimate Analysis of Organic Matter (daf Basis) } \\
\cline { 2 - 9 } & UO $_{2}$ & Organic Matter & Ash & C & H & O & N & S \\
\hline 0 & 0 & 99.8 & 0.2 & 83.2 & 6.8 & 8.3 & 0.1 & 1.6 \\
\hline 11.3 & 12.8 & 79.4 & 7.8 & 86.9 & 5.8 & 7 & 0.1 & 0.2 \\
\hline 18.4 & 20.9 & 70.3 & 8.8 & 85.7 & 4.8 & 9.1 & 0.1 & 0.3 \\
\hline 24.9 & 28.3 & 65.5 & 6.2 & 84.9 & 3.9 & 10 & 0.1 & 1.1 \\
\hline 33.1 & 37.5 & 46.2 & 16.3 & 91.4 & 3.2 & 4.8 & 0.1 & 0.5 \\
\hline 55.8 & 63.3 & 14.1 & 22.6 & 92.2 & 2.8 & 4.5 & 0 & 0.5 \\
\hline
\end{tabular}

Anthraxolite is a solid bitumen with incorporated uraninite $\left(\mathrm{UO}_{2}\right)$ particles or fragments of tenths of $\mathrm{mm}$ to several $\mathrm{mm}$ in size and admixtures, most commonly coffinite $\left(\mathrm{U}\left(\mathrm{SiO}_{4}\right)_{1-\mathrm{x}}(\mathrm{OH})_{4 \mathrm{x}}\right)$ and calcite, but also but also other, such as pyrite, chalcopyrite and gersdorffite, found e.g. in locality Vrchlabí, Czech Rep. However, the uranium-free form of anthraxolite is also known, but it always occurs in close proximity to uraninite or uraniferous anthraxolite accumulations. The chemical composition of anthraxolite is quite variable, but it can contain up to $80 \%$ of bitumen. On average, anthraxolite may contain $70 \%$ bitumen, $20 \%$ uraninite and $10 \%$ ore minerals (iron pyrite, galenite, sphalerite, silica, calcite and siderite). The composition of uranium and uranium-free anthraxolite is given in Table 1 . Significant anthraxolite deposits are in Central Europe, especially in the Czech Republic. One of the largest known accumulations of anthraxolite in hydrothermal veins is the Late Variscan uranium deposit (275-278Ma) in Př́bram, Czech Rep. Geological setting of the Příbram uranium deposit is given in the work [1]. It is located along the northwestern border of the Central Bohemian pluton (345-335Ma) with low-grade metamorphic Late Proterozoic and non-metamorphic Cambrian rocks. The amount of anthraxolite in the ore veins increases in the direction roughly perpendicular to the contact line with the plutonic body and increases with depth. The bituminous mass of anthraxolite is either amorphous (less common texture) 
or microporous. Morphologically, the solid bitumen can be globular (uranium-free), asphalt-like (uraniferous, low-grade) and coke-like (uraniferous, high-grade). Thus, the yield of extraction with organic solvents is always very low. The following analyzes and conclusions are devoted to the Př́bram anthraxolite as a typical case. Data on the chemical composition of uranium minerals from Czech deposits are quite limited [1]. However, two studies [2,3] have recently been published on the nature and chemical composition of uraninite and coffinite. This work summarizes little known knowledge about the composition and structural features of anthraxolite.

\section{Instrumental Analysis of Anthraxolite Bitumens}

The key to characterizing anthraxolites is the analysis of their bituminous component. Pyrolysis-gas chromatography: Using online pyrolysis, bitumens in the globular uranium-free and coke-like uraniferous anthraxolites were analyzed. In the former case, aliphatic $\left(\mathrm{C}_{1-6}\right)$ and alicyclic hydrocarbons; benzene, methylbenzenes, and cymene; styrene, methylstyrene and divinylbenzene; indane and indene; diphenyl, naphtalene and methylnaphtalenes; acenaphtene, methylacenaphtene and acenaphtylene; fluorene; anthracene, methylanthracene and phenanthrene; and chrysene were identified (Figure 1). In the latter case, the composition of the identified compounds was similar, but the yield of aliphatic hydrocarbons was significantly lower, some methylated benzenes and aromates such as methylnaphtalenes, methylacenaphtene and methylanthracene were not identified. From these results it can be deduced that in bitumen of uraniferous anthraxolite the aliphaticity decreased, contrary, its aromaticity increased compared to uranium-free bitumen. This finding was confirmed by the work [4], which reports the amount of aliphatic and aromatic hydrocarbons in globular uranium-free and uraniferous coke-like bitumens obtained using off-line pyrolysis. From their data it follows that-if we define the aromaticity $\mathrm{f}_{\mathrm{ar}}$ as the ratio of aromatic and total hydrocarbonswhile the $\mathrm{f}_{\mathrm{ar}}$ of globular uranium-free bitumens is only 0.39 or 0.35 , the $f_{\text {ar }}$ of uraniferous coke-like bitumens is 0.64 or 0.58 or 0.55 . It is clear that the aromaticity of the latter is significantly higher.

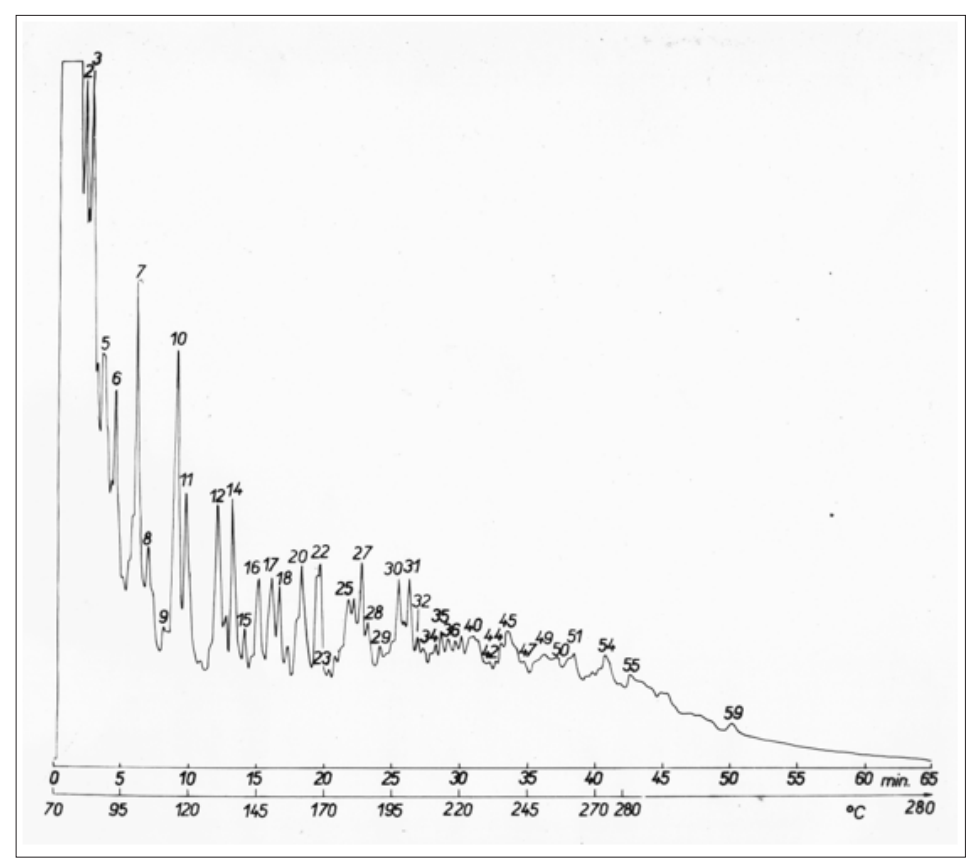

Figure 1: Pyrolysis chromatogram of globular bitumen of uranium-free anthraxolite. Identified hydrocarbons: 1,2 aliphatic hydrocarbons C1-6, 3 benzene, 4-6 alicyclic hydrocarbons, 7 toluene, 10,11 xylenes, 11 styrene, 12 phenol, 14 methylstyrene, 16 indane, 17 indene, 18 cymene, 20 divinylbenzene, 22 naphthalene, 23,24 tetramethylbenzenes, 25 quinoline, 27 2-methylnaphthalene, 28 1-methylnaphthalene, 30 biphenyl, 34,35 dimethylnaphthalenes, 36 acenaphthylene, 40 acenaphthene, 42,44 methylacenaphthene, 45 fluorene, 49 anthracene, 51 methylanthracene, 59 chrysene.

FTIR spectroscopy. Two beneficial results were revealed from FTIR spectra, (a) the presence of both aromatic and aliphatic ketones, (b) while the FTIR spectra of the uranium-free anthraxolite bitumen show aliphatic groups $\mathrm{CH}_{2}$ and $\mathrm{CH}_{3}$, these groups were practically not recorded in uraniferous anthraxolite. The presence of ketones is important to explain the association between uraninite and bitumen. Due to its electron configuration, uranium atom can bound four or more ligands around it, consequently, it forms many complexes, particularly with ligands that have oxygen donor atoms. The affinity of uraninite for bitumen, and thus the formation of anthraxolite, is most likely based on this property of the uranium atom. Another finding concerning the aliphatic groups $\mathrm{CH}_{2}$ and $\mathrm{CH}_{3}$ supports the mentioned result of pyrolysis-gas chromatography, because if these groups do not occur in uraniferous anthraxolite, then the aromaticity of its bitumen is higher compared to uraniumfree anthraxolite bitumen. Thus, generally the FTIR spectra 
of anthraxolite bitumens include five important bands, 2950$2850 \mathrm{~cm}^{-1}$ (stretching vibrations in $\mathrm{CH}_{2}$ and $\mathrm{CH}_{3}$ groups, aliphatic hydrocarbons $), \quad 1730-1685 \mathrm{~cm}^{-1} \quad(\mathrm{C}=0$ stretching vibrations in carbonyls), $1600 \mathrm{~cm}^{-1}$ ( $\mathrm{C}=\mathrm{C}$ stretching), $1448 \mathrm{~cm}^{-1}$ (bending vibrations in $\mathrm{CH}_{2}$ and $\mathrm{CH}_{3}$ groups, aliphatic hydrocarbons) and 800 $625 \mathrm{~cm}^{-1}$ (the out-of-plane $\mathrm{C}-\mathrm{H}$ bending vibrations in polyaromatic rings). Spectra of the asphalt-like bitumens contain all five bands; those of globular uranium-free bitumens lack the band of polyaromatic $\mathrm{C}-\mathrm{H}$ vibrations, and the spectra of uraniferous cokelike bitumens show a significant polyaromatic band while the bands of $\mathrm{CH}_{3}$ and $\mathrm{CH}_{2}$ groups in aliphatics are strongly suppressed. Spectrum of the globular uranium-free bitumen shows (Figure 2) (KBr pellet technique). Representative spectra of uraniferous cokelike bitumen and comparison of them with globular uranium-free bitumen are demonstrated in the work [4, Figure 12]. ${ }^{13} \mathrm{C}$ MAS NMR spectroscopy: ${ }^{13} \mathrm{C}$ MAS NMR spectra showed that the aromaticity of uraniferous anthraxolites was $\mathrm{f}_{\mathrm{ar}}=0.60$ and higher, but that of the uranium-free anthraxolite was $\mathrm{f}_{\mathrm{ar}}=0.50$ only. Thus, aromaticity of bitumen in uraniferous anthraxolite is higher compared to bitumen in uranium-free anthraxolite. This result is consistent with the above findings of pyrolysis-gas chromatography and FTIR and shows that the $\alpha, \beta$ and $\gamma$ radiations from radionuclides $U^{238}$ and $\mathrm{U}^{235}$ aromatize the bituminous mass of anthraxolite, in other words, cleave bonds of aliphatic groups in alkyl-aromatics and other bonds and, subsequently, by radicals, the polycondensed hydrocarbons are formed. The increase in aromaticity and degree of polycondensation with increasing uranium content in the case of coal is reported also by Havelcová et al. [5]. Another study demonstrates a radiolytic alteration in the organic matter of amber [6]. Uranium radionuclide radiation has led to structural changes that have included (a) increased aromatics, (b) loss of oxygen functional groups, (c) increased degree of polymerization, (d) cross-linking and other changes.

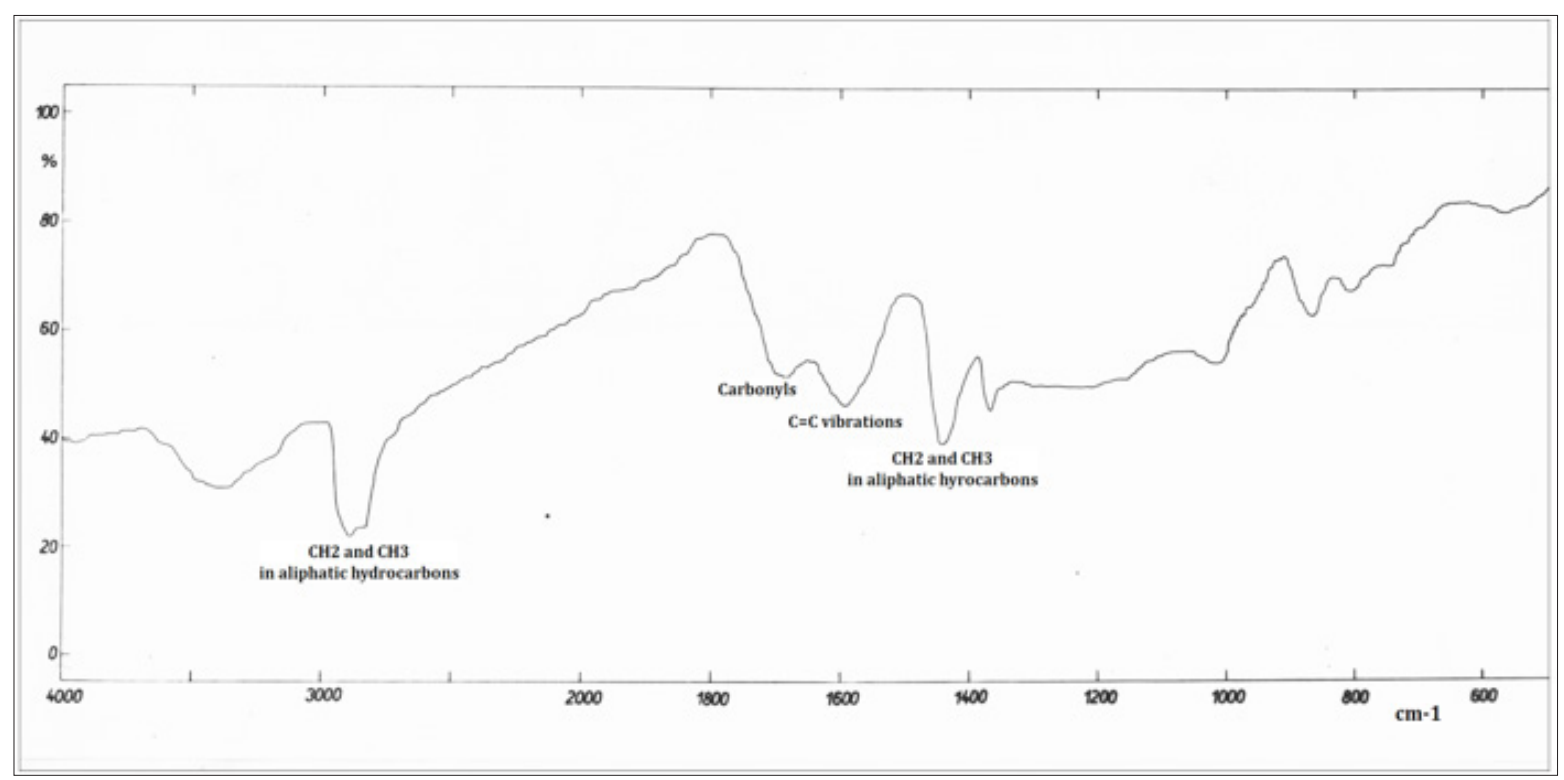

Figure 2: Infrared spectrum of the globular uranium-free bitumen. No significant absorbance in the region $800-$ $625 \mathrm{~cm}-1$ was recorded.

Isotopic ratio ${ }^{12} \mathrm{C} /{ }^{13} \mathrm{C}$. For anthraxolites, Dubanský [7] states the high values of ${ }^{12} \mathrm{C} /{ }^{13} \mathrm{C}$ ratio: 93.86 for uranium-free anthraxolite, 94.38 for uraniferous anthraxolite from the depth $800 \mathrm{~m}$ and 94.24 for that from the depth $600 \mathrm{~m}$. This means that during the transport of highly viscous bitumens by hydrothermal fluids from depths of several $\mathrm{km}$ to depths of several hundred meters, isotopic fractionation took place, and, further, that the bitumens of current anthraxolites are isotopically light. However, this also means that the source of anthraxolite bitumens were the bitumens in sediments of Upper Proterozoic and Cambrium age. Anthraxolites at the Př́bram are younger than the main uranium mineralization. Their age can be estimated at $270 \mathrm{Ma}$, while the age of the uranium deposit is 275278Ma and the Central Bohemian pluton 345-335Ma, as mentioned above.

\section{Other occurrences of anthraxolite}

Anthraxolite is not common but can be found all over the planet. Dubanský [7] reports globular uranium-free bitumens from the eastern part of Germany with high ${ }^{12} \mathrm{C} /{ }^{13} \mathrm{C}$ ratio (91.992.9), Erokhin et al. [8] described anthraxolites from the border of the Ural and western Siberia, other authors report anthraxolites from South China [9] and northern Minnesota [10]. Anthraxolite is sometimes compared to shungite [11].

\section{Outline of anthraxolite genesis}

With respect to the works from Kř́ibek [4] and Dubanský [7] it may be suggested that the source of anthraxolite bitumen were bitumens contained in the Upper Proterozoic and Lower, possibly Middle, Cambrian host rocks. During intrusion of the Central 
Bohemian pluton into sediments, these highly viscous bitumens were mobilized from the contact-metamorphic aureole (possibly they were also partially, but weakly pyrolyzed), then accumulated in structural traps in less heat-affected parts of the sedimentary complex and subsequently extracted and transported with hydrothermal fluids into a uranium deposit. Here, particles and fragments of uraninite penetrated into the highly viscous bitumens, and the bituminous mass was gradually changed by radiation from uranium radionuclides. In other words, bitumens have been metamorphosed by radiation $\alpha, \beta$ and $\gamma$ to polyaromatics coke-like structures. Radiation metamorphosis is also confirmed by methane blow outs from anthraxolite accumulations.

\section{Conclusion}

Anthraxolite is the solid bitumen with incorporated uraninite particles and/or fragments and admixtures (coffinite and ore minerals). Three types were distinguished: globular (uraniumfree), asphalt-like (uraniferous, low-grade), and coke-like (uraniferous, high-grade). Based on analyzes of these three types by advanced instrumental methods, description of Upper Proterozoic and Cambrian sediments, assessment of uranium ore composition and anthraxolite accumulations in hydrothermal veins, the anthraxolite genesis has been outlined. The source of bitumen were the mentioned sediments, whose original biological material was gradually transformed into more homogeneous organic matter, which subsequently polymerized to kerogen as a thermodynamically more stable form. By long-term exposure to temperature and pressure, the kerogen was changed to highly viscous bitumens. After magmatic activity between 345 and $335 \mathrm{Ma}$, these viscous bitumens were transported by hot (250$350{ }^{\circ} \mathrm{C}$ ) hydrothemal fluids from depths of several $\mathrm{km}$ to depths of several hundred meters into a uranium deposit aged 275-278Ma. Here, with uraninite fragments and particles, the uraniferous anthraxolites aged $\sim 270$ Ma were formed, and - always in close proximity to uraninite accumulations - also globular uranium-free anthraxolite originated. Then, the anthraxolite bitumens have been metamorphosed by radiation $\alpha, \beta$ and $\gamma$ to polyaromatics asphaltlike and coke-like structures as low- and high-grade types.

\section{Acknowledgment}

This work was carried out thanks to the support of the LongTerm Project for the Conceptual Development of the Research Organization No. RVO 67985891.

\section{References}

1. René M, Dolníček Z, Sejkora J, Škácha P, Šrein V (2019) Uraninite, coffinite and ningyoite from vein-type uranium deposits of the bohemian massif (Central European Variscan Belt). Minerals 9(123): 1-23.

2. René M (2017) Alteration of granitoids and crystalline rocks and uranium mineralisation in the Bor pluton area, Bohemian Massif, Czech Republic. Ore Geology Reviews 81: 188-200.

3. René M, Dolníček Z (2017) Uraninite, coffinite and brannerite from shear-zone hosted uranium deposits of the bohemian massif (Central European Variscan Belt). Minerals 7(4): 1-17.

4. Kř́ibek B, Žák K, Spangenberg J, Jehlička J, Prokeš S, et al. (1999) Bitumens in the late variscan hydrothermal vein-type uranium deposit of př́bram, Czech Republic: Sources, radiation-induced alteration, and relation to mineralization. Economic Geology 94(7): 1093-1114.

5. Havelcová M, Machovič V, Mizera J, Sýkorová I, Borecká L, et al. (2014) A multi-instrumental geochemical study of anomalous uranium enrichment in coal. Journal of Environmental Radioactivity 137: 52-63.

6. Havelcová M, Machovič V, Mizera J, Sýkorová I, René M, et al. (2016) Structural changes in amber due to uranium mineralization. Journal of Environmental Radioactivity 158-159: 89-101.

7. Dubanský A (1989) Radiation metamorphism of anthraxolite. Technology-geochemistry 24: 31-67.

8. Erokhin YV, Ivanov KS (2019) On the discovery and study of anthraxolite in Triassic plagiorhyolite on the border of the Ural and western Siberia. Geosciences Journal 23: 273-279.

9. Guo F, Li Z, Deng T, Qu M, Zhou W, et al. (2020) Key factors controlling volcanic-related uranium mineralization in the Xiangshan Basin, Jiangxi Province, South China: A Review. Ore Geology Reviews 122: 103517.

10. Hiller JA, Shapiro RS (2009) Detailed petrographic analysis of anthraxolite morphology in the Biwabik Iron-Formation, northern Minnesota. In: Proceedings - $55^{\text {th }}$ Annual Meeting Institute on Lake Superior Geology, Minnesota, USA. pp. 40-41.

11. Golubev YA, Isaenko SI, Prikhodko AS, Borgardt NI, Suvorova EI (2016) Raman spectroscopic study of natural nanostructured carbon materials: shungite vs. anthraxolite. European Journal of Mineralogy 28(3): 545554 .

For possible submissions Click below: 